\title{
UNIVERSAL HEALTH \\ COVERAGE: AN ANALYSIS OF \\ ALTERNATIVE POLICY FOR \\ HEALTH CARE SPENDING IN BANGLADESH
}

\author{
Ali MOHOSHIN1 \\ Shamima AKTER ${ }^{2}$ \\ DOI: 10.35782/JCPP.2021.2.04
}

\begin{abstract}
Health care spending is one of the crucial elements for ensuring universal bealth coverage in Bangladesh. The main purpose of the policy analysis report is to find out policy option of health care spending for ensuring universal bealth coverage in Bangladesh by 2030. The underlying objectives of the study are to examine the effectiveness of existing national health policy to ensure universal health coverage for the people of Bangladesh, to evaluate the current health care spending and to develop alternative policy for ensuring universal health coverage 2030. The policy analysis report has been prepared based on identifying the policy problems from the existing content, document research and organizational records and in doing so the multi-goal policy analysis approach and the criteria of measurement set against the goals and objectives of the policy. Data and information of this policy analysis have been accumulated and presented from various secondary sources. The major findings of the policy analysis can be noted that the policy alternative as policy intervention as such introducing multiple bealth protection schemes and create bealth protection fund especially for the people living below poverty line for ensuring universal health coverage in Bangladesh and thereby the household out of pocket expenditure will decrease significantly. Therefore, it is suggested and can be implemented in the whole country for the sake of ensuring universal health coverage and make accessible of quality health services to the people of Bangladesh. It is also recommended that Bangladesh needs to introduce the health protection schemes at least for the people living below poverty line and the people working in the formal sector. Key words: universal health coverage, health protection fund, health care spending, out- ofpocket expenditure, health insurance
\end{abstract}

\footnotetext{
${ }^{1}$ Dr. Md, Director (Planning, Programming \& Recording), Bangladesh, Public Administration Training Center, Savar, Dhaka, email: mohoshin2005@gmail.com

2 Dr. MBBS, BCS (Health), Diploma in Dermatology \& Dermato-surgery, Medical Officer, Bangladesh Public Administration Training Center, Savar, Dhaka, email: shamimaakterdr@gmail.com
} 


\subsection{Background}

Bangladesh is a developing country of South Asia, having 157.9 million populations with a remarkable annual population growth rate of 1.37 in an area of $147,570 \mathrm{sq} . \mathrm{km}$, having density of more 1142 people per square kilometer, with a low middle income per capita US \$ 1314. Bangladesh is maintaining an outstanding performance of economic growth of more than $6 \%$ of last six years and advanced 14 steps from the $58^{\text {th }}$ to $44^{\text {th }}$ in the world economy in the last two years according to WB and IMF report published in April 2015.

In Bangladesh, widespread improvement has been made in social indicators such as education, health and sanitation. Establishment of 13 thousand 861 community clinics is now at the completion stage. As an impact of this initiative, infant and maternal mortality rates declined significantly while presence of nurse or trained midwives during child birth was ensured. Maternity and infant mortality rates have fallen to 1.7 and 33 per thousand, respectively. Average life expectancy has gone up to 70.7 years from 66.5 years in 2005-2006. Rate of poverty has decreased to 24.3 percent from 40 percent and that of ultra-poor has dipped to 9.9 percent from 24.2 percent in 2015.

Social mobility and empowerment of women are remarkable. Despite remarkable success and improvement in health sector and reaching to the MDGs, like many of the developing countries in the world Bangladesh is facing challenges in the public health care spending and management especially in the areas of adolescent reproductive health, plateauing of the total fertility level (TFR), aging, threat of HIV/AIDS/STD, maternal health, child health, morbidity, education, employment, nutrition, early marriage, dowry, early pregnancy, unwanted pregnancy, unmet contraceptive needs, health hazard due to climate change, environment, food security and gender inequality leads to a greater pressure on resources and limits economic development. As a result of successful intervention on health and family planning, the level of TFR has declined from 6.3 to 2.3 and attainment of replacement level of fertility 2.1 remains a formidable challenge to the policy makers. Even after reaching the replacement level of fertility, it may take quite a long time to attain zero growth rates due to the young age structure of population.

Health care is indispensable for increasing the productivity of human beings. Almost every state in the world are spending a lot and gives priority of government spending on health sectors for human development and economic growth from the increasing and reasonable demand of the citizens as constitutional rights. It is time to analyze whether benefits are going to the targeted citizen which really generating the productivity of human beings and increasing the life expectancy that leads to overall human resource development and eventually sustainable economic development.

\subsection{Policy problem statement}

Considering the current health status and problem of insufficient health care financing for achieving universal health coverage by 2032, it is inevitable to discuss the policy problem for further policy intervention as Bangladesh, yet it did not launch health 
protection fund and other requisite fund with the intent to minimize household out of protect expenditure especially the poorest people of Bangladesh.

\subsection{Healthcare financing}

The Government of Bangladesh has fixed a number of priorities to materialize the national goal of graduating Bangladesh into a middle-income country by 2021, among them the first goal is overall Human Resource Development with special emphasis on Health and Education. The healthcare financing of Bangladesh is strongly dominated by private out-of-pocket payments. The government expenditure is only $26 \%$ as a percentage of total health expenditure. The total public health expenditure of Bangladesh in 2014-2015 is 11146 crore taka. It constitutes 3.7percent of GDP in 2012 compared to 3.5 in 1995. Per capita health expenditure increases to 32 US\$, from \$9 since 2000 (World Health Organization, 2015) and government spends only US\$ 8.32 per capita for health spending. According to World Health Organization, per capita government health expenditure should be at least US \$34. However, health expenditures a percentage of GDP varied between a small range i.e., 2.6 and 3.7 percent during the same period. The financing of public hospitals comes from nondevelopment budget and development budget. While the non-development budget is the source of revenue collected through taxes, the development budget is from Health, Population, and Nutrition Sector Development Program (HPNSDP, 2012-2016). The government hospitals get funds and equipment from the government on the basis of number of beds and organogram of the hospital.

The world average total expenditure on health is $10.0 \%$ of the gross domestic product on health in 2013 and Out-of-pocket expenditure is $18.6 \%$ of total expenditure on health in 2013 and Per capita expenditure is US\$ 1038 for health expenditures in 2013. Among the South Asian countries' Sri Lanka spends US \$ 102 per capita on public health and India spends US\$ 61. Norway spends the highest per capita US\$9715, while United States of America spends US \$9146 per capita on public health. Among the Asian countries, Japan spends the highest per capita on public health, which is US\$ 3966, and Thailand spends US\$ 264 per capita on public health. Japan already experiences 50 years of universal health coverage in 2011 and experienced coverage in 1961. Despite unimaginable improvement of health sectors and health related indicators, the question arises concerning the challenges of universal health coverage through public health care expenditure in Bangladesh.

It seems that about more than half of the people are out of the reach of the government's healthcare facilities and not enjoying government spending till today and about $64 \%$ expenditure comes from the out-of-getting facilities from government sector. Government expenditure are covering only $26 \%$ as a percentage of total expenditure on health in Bangladesh and $8 \%$ coming from NGOs and Donors. Household out of pocket expenditure is $64 \%$ as a percentage of total expenditure on health. Health insurance covers very negligible portion of the total health spending in Bangladesh. Despite of identifying one of the most prioritize sectors the government of Bangladesh spending only $4.3 \%$ on health and family welfare sector as a percentage of total expenditure that also shows decreasing trends in terms of percentage. 
Government spends only US\$ 8.32 out of per capita US\$ 32 total health spending in Bangladesh. According to World Health Organization Commission on macroeconomics and health (2001) the set of essential interventions costs, on average, about $\$ 34$ per person per year, which is much higher than the current level of public spending in Bangladesh. In these circumstances, there is still a long step to go for ensuring universal and quality health-care facilities for all specially the poorest people of the country and it needs alternative policy intervention for universal health coverage by 2032 for the people of Bangladesh.

\subsection{Policy goals and objectives}

Bangladesh is a growing country in the South Asian region and has prioritized the health sector to ensure the universal health coverage and availability of health-related services to all the citizens for overall human resources development. Though the condition of health sector is improving, there are some challenges of universal health coverage with resource constraints. Therefore, it needs proper policy interventions to improve the health coverage of the people of Bangladesh. The policy goals and corresponding objectives are summarized as below.

Table 1. Policy Goals and Objectives

\begin{tabular}{|l|l|}
\hline \multicolumn{1}{|c|}{ Goals } & \multicolumn{1}{|c|}{ Objectives } \\
\hline $\begin{array}{l}\text { Strengthen health care } \\
\text { (Equity) }\end{array}$ & $\begin{array}{l}\text { 1. The main objective of the policy intervention is to } \\
\text { increase public health coverage by reducing out of pocket } \\
\text { expenditure from the current } 64 \% \text { to } 32 \% \text { by } 2032 \text { with } \\
\text { public fund primarily to cover the premium of people living } \\
\text { under below poverty line. } \\
\text { 2. The objective of the policy is to increase government total } \\
\text { health expenditure as a percentage of total heath expenditure } \\
\text { from } 26 \% \text { to at least } 30 \% \text { by } 2032\end{array}$ \\
\hline $\begin{array}{l}\text { Make affordable health } \\
\text { protection schemes to cover } \\
\text { all the people of Bangladesh. } \\
\text { (Efficiency) }\end{array}$ & $\begin{array}{l}\text { 1.To provide free, compulsory contributory and voluntary } \\
\text { participation health care protection for the people living } \\
\text { below poverty line of } 31.5 \%, \text { formal sector of } 12.3 \% \text { and the } \\
\text { informal sector of } 56.2 \% \text { people respectively from less than } \\
1 \% \text { to at least } 32 \% \text { by } 2032 .\end{array}$ \\
\hline $\begin{array}{l}\text { Ensure standard level of } \\
\text { health expenditure (Fiscal } \\
\text { Sustainability/Budget } \\
\text { Availability) }\end{array}$ & $\begin{array}{l}1 . \text { The underlying objective of the policy is to increase total } \\
\text { public expenditure on health per head US } \$ 8.32 \text { to at least } \\
\text { US } \$ 34 \text { by the year } 2032 .\end{array}$ \\
\cline { 2 - 2 } & $\begin{array}{l}2 . \text { To increase total public expenditure at least } 15 \% \text { as a } \\
\text { percentage of total public expenditure from the current } \\
4.3 \% \text { for achieving the universal health coverage by } 2032 .\end{array}$ \\
\hline
\end{tabular}

\subsection{Policy Alternatives}

Alternative should be ways to address or eliminate the policy problem. In constructing alternatives, one can utilize several techniques. Setting policy alternatives is one of the 
fundamental pillars of policy analysis. There are a variety of sources of developing policy alternatives such as existing policy proposals, policies implemented in other jurisdictions, generic policy solutions, custom designed alternatives and build a policy from scratch with creativity and brainstorming. In this project paper two alternatives have been chosen among a few available policy proposals/interventions.

Policy Alternative One (PA1): The National Health Policy 2011 for universal and quality health care for the citizens of Bangladesh. (Status quo)

Policy Alternative Two (PA2): Innovation and Introduction of multiple health Insurance schemes (leading to universal health insurance scheme) with the current national health policy for universal health coverage by 2032 .

\subsection{Description of Policy Alternatives}

Table 2. Descriptions of Policy Alternatives

\begin{tabular}{|c|l|}
\hline $\begin{array}{c}\text { Policy } \\
\text { Alternatives }\end{array}$ & \multicolumn{1}{c|}{ Description } \\
\hline One (PA1): & $\begin{array}{l}\text { This is the current health policy of Bangladesh. Though the main goal } \\
\text { of the policy is to ensure universal primary health care and to ensure } \\
\text { accessibility of the emergency health care services it has not taken } \\
\text { initiative to cover all the people of Bangladesh under the universal } \\
\text { health coverage due to resource constraints. The national health } \\
\text { policy-2011 of the Government of Bangladesh has set its vision, } \\
\text { goals, objectives, principles and strategies to implement and improve } \\
\text { the health status of the people of Bangladesh. It creates the avenues } \\
\text { and opportunity of GO-NGO collaboration, public private } \\
\text { partnership in health sector improvement. It has one vision, 3 goals, } \\
\text { 19objectives, 16 policy principles and 39 strategies. }\end{array}$ \\
\hline Policy Alternative & $\begin{array}{l}\text { This policy gives the window of innovative opportunity of alternative } \\
\text { health care financing through introduction of multiple health Insurance } \\
\text { schemes (leading to universal health insurance scheme) with the existing } \\
\text { national health policy. It will ease to reach the goal of universal health } \\
\text { coverage by 2032. There are three classes of people in Bangladesh } \\
\text { according to the status. About 31.5\% equivalents to 48 million people } \\
\text { are living below poverty line. There are 12.3\% people belongs to } \\
\text { formal and 56.2\% people belong to informal sector. Due to insufficient } \\
\text { health care financing government can introduce multiple health } \\
\text { protection schemes for each group. The people who are living below } \\
\text { poverty line can be covered by creating a health protection fund for } \\
\text { covering their premium. The scheme for the formal sector must be } \\
\text { compulsory and contributory and voluntary participation for the } \\
\text { informal sector. This way Bangladesh can achieve universal health } \\
\text { coverage by 2032. }\end{array}$ \\
\hline
\end{tabular}




\section{Findings from relevant literature}

\section{Alternative 1}

The National Health Policy 2011 for universal and quality health care for the citizens of Bangladesh. (Status quo)

The National Health Policy-2011 of the Government of Bangladesh has set its vision, goals, objectives, principles, and strategies to implement and improve the health status of the people of Bangladesh. It creates the avenues and opportunity of GO-NGO collaboration, public private partnership in health sector improvement. It has one vision, 3 goals, 19objectives, 16 policy principles and 39 strategies. The main goal of the policy is to ensure universal primary health care and to ensure accessibility of the emergency health care services. There are some strong factors that put the country on track to achieve the health-related Millennium Development Goals that found in several findings.

1. The prioritization of family planning, awareness building of reproductive health among the adolescents. 2. The development of human resources, particularly availability of doctors, paramedics, health assistants and family-welfare assistants. 3. Progressive policies outside the health sector, including education and female empowerment and female education.4. Facilitated access to health facilities and information.5. Mobility of man and women due to rural infrastructure improvement.6. Awareness building through campaign and immunization and distribution of vitamin and other medicine through health campaign. The NGOs are doing appreciable job for health awareness building.7. Supply of low-cost medicine through local production. 8. Coverage of $100 \%$ sanitation campaign and implementation and campaign of hand washing and pure drinking water. 9. Innovation of saline of diarrheal diseases. Bhuiya Abbas (2015) stated that Universal Health Coverage (UHC) is a top priority for Bangladesh.

He has mentioned that it is expected to have access to needed quality health care services without any financial hardship for the people of Bangladesh. On the other hand, Islam Touhidul (2015), referred that Bangladesh has made substantial progress over the two decades but still $64 \%$ of health expenditure comes out of pocket which is very alarming. Moreover Hossain (2015), the issue of UHC and the issue of health in general have become significantly more important and need to have the cutting edge that will bring the policy on the board for the UHC to implement for the people of Bangladesh.

\section{Alternative 2}

Innovation and Introduction of multiple health Insurance schemes (leading to universal health insurance scheme) with the current national health policy for universal health coverage by 2032 .

Buracom, 2011 stated that the public spending on health in Thailand includes on hospital, health centre management, disease prevention and control and promotion. The expansion of health insurance scheme is an instrument for Thai citizens and since, 
1988, government has introduced a publicly-subsidized healthcare schemes to increase the access of low-income families to health care services. He also mentioned that in 1997, government introduced a universal health care system that covers every Thai citizen. ILO (2008) referred that the universal coverage for health care was started as a national strategic policy under the slogan '30 Bath to cure every disease. (NaRanong \& NaRanong, 2006) mentioned that the universal health care coverage scheme or the 30 Bath schemes covers everyone who is not covered by other government sponsored forms of insurance. (Champook et al, 2009) on the other end mentioned that the sources of health funding are paid through different ministries related to health care such as university hospitals, military hospitals, and other health care programmes. HuiKelvin (2015), mentioned that UHC is not only about access but also about quality of health service. He also referred that there are countries which pools money differently, through a system of social health insurances and give patients the choice of accessing either private or public facilities which has also done very well in achieving UHC. Hussain A. M. Zakir (2015), referred that social health insurance is a UHC, which is a mandatory process, where somebody is paying for somebody else, in addition to his or her own, although he/she doesn't need services all the time. NaRanong, V \& NaRanong, A. (2006) mentioned that until the year 2000, approximately $30 \%$ of the Thai population had no health insurance coverage. In 2001, the Thai government, to improve access to care and reduce healthcare disparity between the insured and uninsured Thais, implemented the 30-Baht Health Insurance (HI) Policy for the uninsured Thai population.

\subsection{Objectives}

The underlying objective of the policy analysis is to find out best alternative policies for health care financing that can ensure the universal health coverage and accessibility of quality health services to the citizens of Bangladesh. The main objectives of the study of the policy project paper and policy analysis are as follows.

I. To examine the effectiveness of existing national health policy of Bangladesh to ensure the universal health coverage for the people of Bangladesh.

II. To evaluate the current health care spending is good enough for ensuring universal health coverage.

III. To suggest a mechanism for achieving the target of universal health coverage in terms of financing.

IV. To develop and suggest best alternative policy for ensuring universal health coverage and quality health services by 2032 .

V. To examine the existing national health care policy and spending and coverage trends to reach the goal of the universal health coverage by 2032 . 


\subsection{Scopes}

The study is confined with the current national health policy of Bangladesh and alternative practices in other jurisdiction and framing other policy alternatives by brainstorming or custom-designed alternatives. I will mainly concentrate my policy analysis to health care financing and coverage to attain the goal of Universal Health Coverage under the current national health policy of Bangladesh and introduction of multiple health Insurance schemes (leading to universal health insurance scheme).

\subsection{Methods and data sources}

\subsubsection{Data Collection Approach}

Gathering evidence for policy analysis can be usefully divided into two broad arrays such as document research and field research. In this analysis, I have employed document search research technique to gather necessary evidences and information from a wide variety of literatures including: i) journal articles, books and dissertations; ii) publications and reports; iii) government publications and research documents; iv) online resources and v) relevant policy documents. This method has facilitated to have a clear idea about the policy problem and prospective policy alternatives.

\subsubsection{Policy Analysis Approach}

Policy analysis comprises a good number of approaches and types. Rationalist model suggests five basic approaches to policy analysis such as: formal benefit-cost analysis, qualitative benefit-cost analysis, modified benefit-cost analysis, cost effectiveness analysis, and multi-goal policy analysis. All these approaches are different from each other in terms of their contextual dimensions, socio-economic implications, availability of data, time and resources, scope and usefulness. In this policy analysis, I have considered multi-goal analysis approach as the most appropriate. The rationalist model recommends apply a multi-goal analysis approach when there is efficiency plus two additional goals and when one of the two goals cannot be quantified. It is also suggested that when a policy analysis has two additional goals to efficiency goal and when the impacts of these goal are not quantifiable, the policy analysis should follow a multi-goal analysis approach. Some of the policy outcome and impacts of the goals of the policy analysis are not quantifiable. Therefore, a multi-goal approach of policy analysis is better for making a systematic comparison among available alternatives and assessing their policy outcome and impacts. Therefore, in consonance with the scope, relevance, suitability, and the usefulness of the policy analysis, I have employed a multigoal analytical approach as the best way of policy analysis because policy performance depends on multi factors not only the benefit and cost associated with it. 
54 An analysis of alternative policy for health care spending in Bangladesh

\subsection{Data Sources and Analysis}

Data of this analysis have been gathered and examined based on the criteria set against the goals and objectives of a particular policy. Based on the literature review, I have analyzed the data and information against the criteria and objectives in different alternatives taking the status quo as the basis. Data and information of this policy analysis have been accumulated, and presented from various sources like Bangladesh Economic Review, The Budget of Bangladesh, Ministry of Health and Family Welfare, World Health Organization, World Bank, Bangladesh Health Bulletin DGHS, Bangladesh Demographic and Health Survey, Bangladesh Bureau of Statistics, data from some other document research.

\subsection{Goal: Strengthen health care (Equity)}

Objectives: 1. the main objective of the policy intervention is to increase public health coverage by reducing out of pocket expenditure from the current $64 \%$ to $32 \%$ by 2032 with public fund primarily to cover the premium of people living under below poverty line.

Criteria: Minimizing Out- of- Pocket (OOP) Expenditure from 64\% to at least 32\%.

The household and government and other sources expenditure health expenditure data are important factor for analyzing the goals and objectives and its measurement. The table-4 bellows the health expenditures both government and private and the household out of pocket expenditure. Figure-2 shows.

Table 3: Health Expenditure data- Bangladesh

\begin{tabular}{|c|c|c|c|c|c|c|c|c|}
\hline Year & \begin{tabular}{|c|} 
Total \\
expenditure \\
on health \\
as a \\
percentage \\
of gross \\
domestic \\
product
\end{tabular} & $\begin{array}{c}\text { General } \\
\text { government } \\
\text { expenditure } \\
\text { on health as } \\
\text { a percentage } \\
\text { of total } \\
\text { expenditure } \\
\text { on health }\end{array}$ & $\begin{array}{l}\text { Private } \\
\text { expenditure } \\
\text { on health } \\
\text { as a } \\
\text { percentage } \\
\text { of total } \\
\text { expenditure } \\
\text { on health }\end{array}$ & $\begin{array}{c}\text { General } \\
\text { government } \\
\text { expenditure } \\
\text { on health } \\
\text { as a } \\
\text { percentage } \\
\text { of total } \\
\text { government } \\
\text { expenditure }\end{array}$ & $\begin{array}{l}\text { External } \\
\text { resources } \\
\text { for health } \\
\text { as a } \\
\text { percentage } \\
\text { of total } \\
\text { expenditure } \\
\text { on health }\end{array}$ & \begin{tabular}{|c|} 
Social \\
security \\
expenditure \\
on health \\
as a \\
percentage \\
of general \\
government \\
expenditure \\
on health
\end{tabular} & 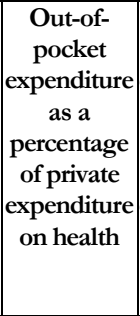 & \begin{tabular}{|c|} 
Out-of- \\
pocket \\
expenditure \\
as a \\
percentage \\
of total \\
expenditure \\
on health
\end{tabular} \\
\hline 2016 & 2.37 & & & & & & & $\begin{array}{c}71.89 \\
(24.6 \\
\text { USD) }\end{array}$ \\
\hline 2012 & 3.7 & 26.0 & 64.7 & 7.8 & 8.0 & 0 & 93 & 64.0 \\
\hline 2000 & 2.6 & 40.7 & 59.3 & 7.4 & 7.3 & 0 & 97.4 & 57.8 \\
\hline 1995 & 3.5 & 36.2 & 63.8 & 8.8 & 3 & 0 & 96.1 & 61.3 \\
\hline
\end{tabular}

Source: World Health Organization and World Bank 
Table 4: Total Health Expenditure related data -Bangladesh

\begin{tabular}{|c|c|c|c|}
\hline Year & $\begin{array}{c}\text { Total expenditure on } \\
\text { health as a percentage of } \\
\text { gross domestic product }\end{array}$ & $\begin{array}{c}\text { Government health } \\
\text { expenditure in relation } \\
\text { to GDP }\end{array}$ & $\begin{array}{c}\text { Out-of-pocket } \\
\text { expenditure as a } \\
\text { percentage of total } \\
\text { expenditure on health }\end{array}$ \\
\hline 2015 & 2.37 & $0.69 \%$ & $67 \%(24.6$ USD) \\
\hline 2012 & 3.7 & & 64.0 \\
\hline 2000 & 2.6 & & 57.8 \\
\hline 1995 & 3.5 & & 61.3 \\
\hline
\end{tabular}

Source: World Health Organization and World Bank

Table 5: Out-of-pocket expenditure as a percentage of total expenditure on health in selected countries

\begin{tabular}{|l|c|}
\hline \multicolumn{1}{|c|}{ Country } & $\begin{array}{c}\text { Out-of-pocket expenditure as a percentage } \\
\text { of total expenditure on health (2017) }\end{array}$ \\
\hline Bangladesh & $71.8 \%$ \\
\hline China & $32.4 \%$ \\
\hline India & $65.1 \%$ \\
\hline Thailand & $11.8 \%$ \\
\hline Japan & $13.1 \%$ \\
\hline Malaysia & $36.7 \%$ \\
\hline UK & $14.8 \%$ \\
\hline USA & $11.1 \%$ \\
\hline Norway & $14.3 \%$ \\
\hline Switzerland & $28.3 \%$ \\
\hline Sweden & $15.2 \%$ \\
\hline Vietnam & $43.5 \%$ \\
\hline South Korea & $36.8 \%$ \\
\hline Nepal & $60.4 \%$ \\
\hline Sri Lanka & $38.4 \%$ \\
\hline
\end{tabular}

Figure 1: Health care financing source in Bangladesh 2012

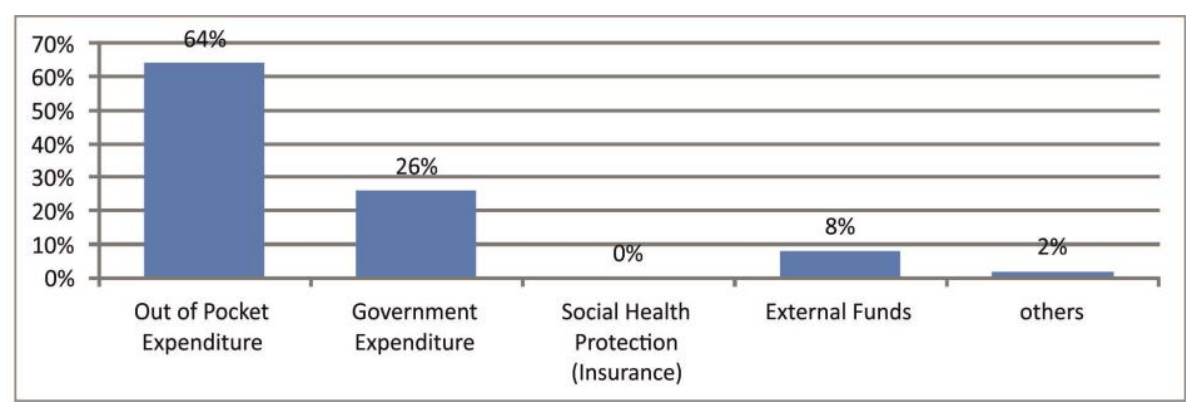


56 An analysis of alternative policy for health care spending in Bangladesh

Figure 2: Projected Health Care financing in Bangladesh in 2032

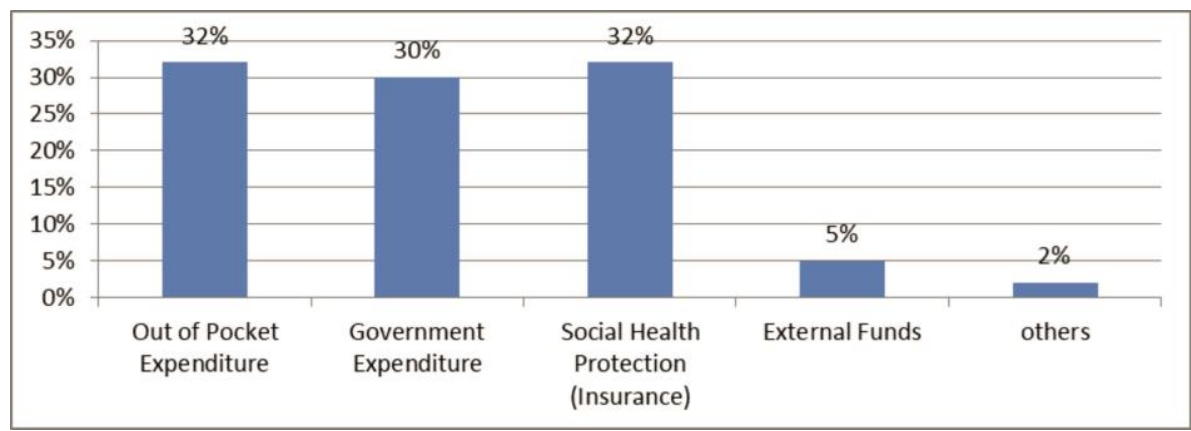

Source: compiled from World Bank data

From the above table- 4 and figure- 2 we have seen that in 1995 the out-of-pocket expenditure or the household on health was $61.3 \%$. The figure shows that the poor people spend a lot for getting the health services. In 1995 to 2000 the situation improves and out of pocket (OOP) reduces to $57.8 \%$ due to increasing government expenditure. But again, in around 2012 the out of pocket expenditure increases to $64.0 \%$ as the government expenditure on health decreases as a percentage of total government expenditure. This is a contradiction of government health policy and prioritization of health sector as total expenditure on health sector decrease from 2009 to current fiscal year. So, it will not be possible to decrease the percentage of out of pocket (OOP) expenditure to $32 \%$ by 2032. If the government spends in current trend then it may increase the household out of pocket (OOP) expenditure again. It needs huge investment in the public health sector. It shows that government expenditure covers only $26 \%$ of total health expenditure in Bangladesh in 2012. Here we need alternative sources of financing besides the government expenditure by introducing multiple health insurance schemes (leading to universal health insurance) to cover the household out of pocket expenditure.

Table 6: Summary of health care financing sources and prediction

\begin{tabular}{|c|c|c|c|}
\hline Policy Alternatives & $\begin{array}{c}\text { Household Out } \\
\text { of Pocket (OOP) } \\
\text { Expenditure }\end{array}$ & $\begin{array}{c}\text { Social Health } \\
\text { Protection }\end{array}$ & $\begin{array}{c}\text { Government } \\
\text { Expenditure } \\
\text { coverage }\end{array}$ \\
\hline PA-1 (status qua) & $67 \%$ & $\begin{array}{c}<1 \% \text { (providing by } \\
\text { some private life } \\
\text { insurance companies } \\
\text { and NGOs) }\end{array}$ & $23.0 \%$ \\
\hline $\begin{array}{c}\text { PA-2 (status qua plus } \\
\text { multiple health } \\
\text { insurance schemes }\end{array}$ & $32 \%$ & $32 \%$ & $30 \%$ \\
\hline
\end{tabular}

Source: Corresponding data from WHO, documents, scientific literature, and prediction 


\subsection{Goal: Make affordable health protection scheme to cover all the people of Bangladesh (Efficiency)}

Objective: To provide free, compulsory contributory and voluntary participation health care protection for the people living below poverty line of $31.5 \%$, formal sector of $12.3 \%$ and the informal sector of $56.2 \%$ people respectively from the less than $1 \%$ to at least $32 \%$ by 2032 .

Criteria: Increase the number of coverages by $33 \%$ within every 5 years and bring them by 2032 to the multiple health Protection scheme.

There are three classes of people in Bangladesh according to the status. About 31.5\% equivalents to 48 million people are living below poverty line. If government can create health protection fund for payment of premium for the poor people to protect them from health hazards that can reduce out of pocket expenditure. As we have seen that the aim of government is to reduce out of pocket expenditure from $64 \%$ to $32 \%$ but increases overtime. The underlying cause of the increase is decreasing trends of government health expenditure as percentage of total expenditure.

Table 7: Summary of expenditure coverage by health protection schemes and government expenditure

\begin{tabular}{|c|c|c|}
\hline & PA-1 (status qua) & $\begin{array}{l}\text { PA-2 (status qua plus } \\
\text { multiple health insurance } \\
\text { schemes) }\end{array}$ \\
\hline $\begin{array}{l}\text { Expenditure Coverage by } \\
\text { government as percentage of total } \\
\text { health expenditure }\end{array}$ & $26 \%$ & $30 \%$ \\
\hline $\begin{array}{l}\text { Free health care protection for the } \\
\text { people living below poverty line } \\
\text { of } 31.5 \% \\
\text { (Social Health Protection) }\end{array}$ & \multirow{3}{*}{$\begin{array}{l}<1 \% \\
\text { (by some life insurance } \\
\text { companies and NGOs) } \\
\text { Now covering average } \\
26.0 \% \text { without } \\
\text { protection scheme) }\end{array}$} & \multirow{3}{*}{$32 \%$} \\
\hline $\begin{array}{l}\text { Formal sector }(12.3 \%) \text { people } \\
\text { under compulsory contributory } \\
\text { health protection }\end{array}$ & & \\
\hline $\begin{array}{l}\text { Voluntary participation of the } \\
\text { informal sector of } 56.2 \% \text { people } \\
\text { under the community-based } \\
\text { health protection scheme }\end{array}$ & & \\
\hline
\end{tabular}

Source of data: own prediction based on data.

Health protection fund can reduce the OOP expenditure. So, the ultimate target depends on health protection fund. Government yet did not allocate the health protection fund, if government allocate health protection fund it can cover the people who living below poverty line by the year 2032. In case of formal sector of $12.3 \%$ amounting to 18.8 million people government do not need money. It only needs introduction compulsory and contributory health protection schemes for public servant 
and private sector workforce. It seems to me it can cover almost all the formal sector people. On the other hand, in the informal sector $56.2 \%$ totaling 85.7 million people would be a great challenge to bring them within the coverage with the voluntary participation to the health protection scheme. To the best of my prediction without government contribution it would not be possible to bring them by the year 2032. So, if government introduces multiple health protection schemes as the alternative sources of health care financing besides the government expenditure it could cover approximately $32 \%$ people especially the poor and the formal sector workforce.

\subsection{Goal: Ensure standard level of health expenditure (Fiscal Sustainability/Budget Availability)}

Objectives:

1. The underlying objective of the policy is to increase total public expenditure on health per head US\$ 8.32 to at least US \$34 by the year 2032 .

2. The objective of the policy proposal is to increase total public expenditure at least $15 \%$ as a percentage of total public expenditure from the current $4.3 \%$ for achieving the universal health coverage by 2032 .

Criteria: 1. Increase per capita health expenditure. 2. Increase and maintain the progressive trends of expenditure.

Table 8: Per capita total health expenditure of some selected countries

\begin{tabular}{|l|c|c|c|}
\hline Country & $\begin{array}{c}\text { Per capita total } \\
\text { expenditure on } \\
\text { health at average } \\
\text { exchange rate (US\$) } \\
\mathbf{2 0 1 5}\end{array}$ & $\begin{array}{c}\text { Per capita total } \\
\text { expenditure on } \\
\text { health at average } \\
\text { exchange rate (US\$) } \\
\mathbf{2 0 1 3}\end{array}$ & $\begin{array}{c}\text { Per capita total } \\
\text { expenditure on } \\
\text { health at average } \\
\text { exchange rate } \\
\text { (US\$) 2012 }\end{array}$ \\
\hline Bangladesh & $37(2015)$ & 32 & 26 \\
\hline Bhutan & $\mathrm{n} / \mathrm{a}$ & 90 & 90 \\
\hline China & 688 & 367 & 322 \\
\hline India & 209 & 61 & 58 \\
\hline Japan & 4766 & 3966 & 4787 \\
\hline Malaysia & $\mathrm{n} / \mathrm{a}$ & 423 & 418 \\
\hline Maldives & $\mathrm{n} / \mathrm{a}$ & 720 & 36 \\
\hline Nepal & $\mathrm{n} / \mathrm{a}$ & 39 & 9312 \\
\hline Norway & 6187 & 9715 & 34 \\
\hline Pakistan & $\mathrm{n} / \mathrm{a}$ & 37 & 247 \\
\hline Sri Lanka & $\mathrm{n} / \mathrm{a}$ & 102 & 8845 \\
\hline Thailand & 600 & 264 & 3595 \\
\hline USA & 10586 & 9146 & 3598 \\
\hline United Kingdom & 4070 & \multicolumn{2}{c|}{ Source: World Health Organization }
\end{tabular}


Table 9: Per capita total health expenditure of some selected countries

\begin{tabular}{|l|c|c|c|}
\hline Country & $\begin{array}{c}\text { Per capita total } \\
\text { expenditure on health at } \\
\text { average exchange rate } \\
\text { (US\$) 2015 }\end{array}$ & $\begin{array}{c}\text { Per capita total } \\
\text { expenditure on } \\
\text { health at average } \\
\text { exchange rate } \\
\text { (US\$) 2013 }\end{array}$ & $\begin{array}{c}\text { Per capita total } \\
\text { expenditure on } \\
\text { health at average } \\
\text { exchange rate } \\
\text { (US\$) 2012 }\end{array}$ \\
\hline Bangladesh & $37(2015)$ & 32 & 26 \\
\hline China & 688 & 367 & 322 \\
\hline India & 209 & 61 & 58 \\
\hline Japan & 4766 & 3966 & 4787 \\
\hline Norway & 6187 & 9715 & 9312 \\
\hline Thailand & 600 & 264 & 8845 \\
\hline USA & 10586 & 9146 & 3595 \\
\hline $\begin{array}{l}\text { United } \\
\text { Kingdom }\end{array}$ & 4070 & 3598 & \\
\hline
\end{tabular}

Table 10: Annual Development Programme (Crore Tk. and as \% of ADP)

\begin{tabular}{|l|c|c|c|c|c|c|}
\hline \multicolumn{1}{|c|}{ Sector } & $\mathbf{2 0 1 2 - 1 3}$ & $\mathbf{2 0 1 3 - 1 4}$ & $\mathbf{2 0 1 4 - 1 5}$ & $\mathbf{2 0 1 5 - 1 6}$ & $\mathbf{2 0 1 6 - 2 0 1 7}$ & 2017-2018 \\
\hline Health & 3995.54 & 4219.79 & 5043.01 & 5331 & 5655.33 & 10201.37 \\
Nutrition & $7.63 \%$ & $7.03 \%$ & $5.86 \%$ & $5.4 \%$ & & \\
Population & & & & & & \\
Family Welfare & & & & & & \\
\hline
\end{tabular}

Source: Bangladesh Economic Review 2015 and Budget 2015-2015

Table 11: Non-Development and Development expenditure of Health and Family welfare sector in Bangladesh (Crore Tk.)

\begin{tabular}{|l|c|c|c|c|c|}
\hline \multicolumn{1}{|c|}{ Sector } & $\mathbf{2 0 1 1 - 1 2}$ & $\mathbf{2 0 1 2 - 1 3}$ & $\mathbf{2 0 1 3 - 1 4}$ & $\mathbf{2 0 1 4 - 1 5}$ & $\mathbf{2 0 1 5 - 1 6}$ \\
\hline Health and & 8869 & 9130 & 9955 & 11146 & 12695 \\
Family welfare & $5.4 \%$ & $4.9 \%$ & $4.3 \%$ & $4.4 \%$ & $4.3 \%$ \\
\hline
\end{tabular}

Source: Bangladesh Economic Review 2015 and Budget 2009-2010 to 2015-2016

Table 12: Estimated and Projected Public Expenditure Required for UHC in Bangladesh, Million Taka

\begin{tabular}{|c|c|c|c|c|c|}
\hline \multicolumn{1}{|c|}{ Indicators } & $\mathbf{2 0 0 9 - 1 0}$ & $\mathbf{2 0 1 4 - 1 5}$ & $\mathbf{2 0 1 9 - 2 0}$ & $\mathbf{2 0 2 4 - 2 5}$ & $\mathbf{2 0 3 1 - 3 2}$ \\
\hline $\begin{array}{l}\text { A. Total public health expenditure } \\
\text { ideally required for UHC }\end{array}$ & 274,173 & 308,763 & 340,899 & 376,381 & 436,381 \\
\hline $\begin{array}{l}\text { B. Estimated healthcare budget with } \\
6 \% \text { growth }\end{array}$ & 68,320 & 91,427 & 122,350 & 163,732 & 232,499 \\
\hline $\begin{array}{l}\text { C.Deficit to achieve UHC (million } \\
\text { taka) (B-C) }\end{array}$ & 205,853 & 217,335 & 218,549 & 212,648 & 203,882 \\
\hline $\begin{array}{l}\text { D. Amount of budget if government } \\
\text { provides 50\% of ideally required } \\
\text { budget (50\% of B) }\end{array}$ & 137,086 & 154,382 & 170,450 & 188,190 & 218190.5 \\
\hline
\end{tabular}

Source: World Bank (adapted from Bangladesh Health Watch 2012) and own projection 
Let us look at the table 7 above per capita total health expenditure of Bangladesh is only us\$32 lowest among the South Asian countries and government spends only US\$8.32. Norway's total expenditure on health is highest in the world US\$9715 and Japan spends uS\$3966 that is highest among the Asian countries (Table 7). Thailand spends US $\$ 264$ on total health expenditure. So Bangladesh is in the worst position as total expenditure on health. Bangladesh spends $3.7 \%$ as a percentage of gross domestic products in 2012. It needs to increase the health expenditure as percentage of gross domestic products and also per capita total health expenditure in both public and personal in order to maintain good health. If we analyze the data on total health expenditure as a percentage total expenditure it shows that in fiscal year 2009-2010 it spends $6.1 \%$ of total expenditure and after that it tends to decrease every year to $4.3 \%$ in 2015-2016 (Table 9). So, the projection of universal health coverage would not be possible with the current trends of total expenditure on health as percentage of total expenditure. The projected and estimated public expenditure is far behind the current level of expenditure and budget deficit may be around 203,882 million takas in 2032 (Table 10).

\section{Policy Analysis Criteria and Measurement}

Criteria are used to measure the outcomes and impacts of each alternative and specifying relevant criteria for assessing how well each policy alternative contributes to each of the goals. There are several criteria commonly used by the policy analysts as 1) Efficacy/Efficiency/Effectiveness, 2) Cost, 3) Administrative Feasibility, 4) Unintended consequences, 5) Equity, 6) sustainability and 7) Political Feasibility. Policy analysis criteria provide a basis for analyzing the relative worth and effectiveness of the policy alternatives. It helps measuring progress towards achieving goals. In this analysis, I have developed a matrix with a view to displaying the impacts of each criterion on each of the policy alternatives. The snap-shots of the predicted impacts have been captured from the data analysis and literature review sections. Rationalist model suggested that predicted impacts can be demonstrated in qualitative terms since measuring some impacts are in quantitative terms seem to be difficult. Therefore, I rate the policy alternatives with three categories of terms. The first category terms are 'very good, 'good', 'poor' and 'bad', and the second category terms are 'High', 'Medium', 'Low' and 'Nil'. I use third category rating as 'Exceeds minimum standard', 'Meets minimum standard', 'Below minimum standard' and 'Well-below minimum standard'. I rate them on the basis of comparison made among the policy alternatives against each of the goals. The comparison has been illustrated below: 
Table 14: Matrix-Structure of Comparative Analysis

\begin{tabular}{|c|c|c|c|c|}
\hline \multirow{2}{*}{ Goal } & \multirow[b]{2}{*}{ Objectives } & \multirow{2}{*}{$\begin{array}{c}\text { Criteria for } \\
\text { measurement }\end{array}$} & \multicolumn{2}{|c|}{ Policy Alternatives } \\
\hline & & & PA-1 & PA-2 \\
\hline \multirow[t]{2}{*}{$\begin{array}{l}\text { Strengthen } \\
\text { health care } \\
\text { (Equity) }\end{array}$} & $\begin{array}{l}\text { 1. The main objective of } \\
\text { the policy intervention is } \\
\text { to increase public health } \\
\text { coverage by reducing out } \\
\text { of pocket expenditure } \\
\text { from the current } 64 \% \text { to } \\
32 \% \text { by } 2032 \text { with public } \\
\text { fund primarily to cover } \\
\text { the premium of people } \\
\text { living under below } \\
\text { poverty line. }\end{array}$ & $\begin{array}{l}\text { Minimizing Out } \\
\text { Of Pocket } \\
\text { (OOP) } \\
\text { Expenditure } \\
\text { from } 64 \% \text { to at } \\
\text { least } 32 \% .\end{array}$ & $\begin{array}{l}64.0 \% \\
\text { Poor }\end{array}$ & $\begin{array}{l}32 \% \\
\text { Good }\end{array}$ \\
\hline & $\begin{array}{l}\text { 2. The objective of the } \\
\text { policy is to increase } \\
\text { government total health } \\
\text { expenditure as a } \\
\text { percentage of total heath } \\
\text { expenditure from } 26 \% \text { to } \\
\text { at least } 30 \% \text { by } 2032\end{array}$ & $\begin{array}{l}\text { Increase } \\
\text { government } \\
\text { health } \\
\text { expenditure from } \\
26 \% \text { to } 30 \%\end{array}$ & $\begin{array}{l}26 \% \\
\text { Poor }\end{array}$ & $\begin{array}{l}30 \% \\
\text { Good }\end{array}$ \\
\hline $\begin{array}{l}\text { Make affordable } \\
\text { health protection } \\
\text { scheme to cover } \\
\text { all the people of } \\
\text { Bangladesh. } \\
\text { (Efficiency) }\end{array}$ & $\begin{array}{l}\text { 1.To provide free, } \\
\text { compulsory contributory } \\
\text { and voluntary } \\
\text { participation health care } \\
\text { protection for the people } \\
\text { living below poverty line } \\
\text { of } 31.5 \% \text {, formal sector of } \\
12.3 \% \text { and the informal } \\
\text { sector of } 56.2 \% \text { people } \\
\text { respectively from less } \\
\text { than } 1 \% \text { to at least } 32 \% \\
\text { by } 2032 \text {. }\end{array}$ & $\begin{array}{l}\text { Increase the } \\
\text { number of } \\
\text { coverages from } \\
\text { less than } 1 \% \text { to } \\
\text { at least } 32 \% \text { by } \\
2032 \text { through } \\
\text { multiple health } \\
\text { protection } \\
\text { scheme }\end{array}$ & $\begin{array}{l}<1 \% \text { (by } \\
\text { some life } \\
\text { insurance } \\
\text { companies } \\
\text { and } \\
\text { NGOs) } \\
\text { Nil }\end{array}$ & Medium \\
\hline \multirow[t]{2}{*}{$\begin{array}{l}\text { Ensure standard } \\
\text { level of health } \\
\text { expenditure } \\
\text { (Fiscal } \\
\text { Sustainability/B } \\
\text { udget } \\
\text { Availability) }\end{array}$} & $\begin{array}{l}\text { 1. The underlying } \\
\text { objective of the policy is } \\
\text { to increase total public } \\
\text { expenditure on health per } \\
\text { head US } \$ 8.32 \text { to at least } \\
\text { US } \$ 34 \text { by the year } 2032 \text {. }\end{array}$ & $\begin{array}{l}\text { Increase per capita } \\
\text { public health } \\
\text { expenditure }\end{array}$ & $\begin{array}{l}\text { Well- } \\
\text { Below } \\
\text { Minimum } \\
\text { Standard } \\
\text { US } \$ 8.32\end{array}$ & $\begin{array}{l}\text { Meets } \\
\text { minimu } \\
\mathrm{m} \\
\text { Standard } \\
\text { US\$34 }\end{array}$ \\
\hline & $\begin{array}{l}\text { 2. To increase total public } \\
\text { expenditure at least } 15 \% \\
\text { as a } \% \text { of total public } \\
\text { expenditure from the } \\
\text { current } 4.3 \% \text { for } \\
\text { achieving the universal } \\
\text { health coverage by } 2032 \text {. }\end{array}$ & $\begin{array}{l}\text { Increase and } \\
\text { maintain the } \\
\text { progressive } \\
\text { trends of } \\
\text { expenditure }\end{array}$ & $\begin{array}{l}4.3 \% \\
\text { Below } \\
\text { minimum } \\
\text { Standard } \\
\text { (Budget } \\
\text { Constraints) }\end{array}$ & $\begin{array}{l}15 \% \\
\text { Meets } \\
\text { minimum } \\
\text { Standards } \\
\text { (Huge } \\
\text { budget } \\
\text { required) }\end{array}$ \\
\hline
\end{tabular}




\section{Predicting and Valuing Impacts of Policy Alternatives}

Before evaluating the policy alternatives in terms of criteria, it is important to measure their impacts in quantitative indicators. The values put against each criterion are extremely helpful to judge the prospective performance of each of the alternative. In this analysis I have used three categories of indicators. I have scored them in the following manner:

Table 15. Indicators and Related Scoring

\begin{tabular}{|c|c|c|c|c|}
\hline Score Value & Score 3 (Highest) & Score 2 & Score 1 & $\begin{array}{c}\text { Score 0 } \\
\text { (Lowest) }\end{array}$ \\
\hline $\begin{array}{c}\text { Measurement } \\
\text { Indicators }\end{array}$ & $\begin{array}{c}\text { Exceeds minimum } \\
\text { standard }\end{array}$ & $\begin{array}{c}\text { Meets } \\
\text { minimum } \\
\text { standard }\end{array}$ & $\begin{array}{c}\text { Below } \\
\text { minimum } \\
\text { standard }\end{array}$ & $\begin{array}{c}\text { Well-below } \\
\text { minimum } \\
\text { standard }\end{array}$ \\
\cline { 2 - 5 } & Very good & Good & Poor & Bad \\
\cline { 2 - 5 } & High & Medium & Low & Nil \\
\hline
\end{tabular}

On the basis of above measurement criteria, I have prepared the following worksheet for predicting impacts of alternative polices.

Table 16. Comparative score card

\begin{tabular}{|c|c|c|c|c|}
\hline \multirow[b]{2}{*}{ Goal } & \multirow[b]{2}{*}{ Objectives } & \multirow{2}{*}{$\begin{array}{l}\text { Criteria for } \\
\text { measurement }\end{array}$} & \multicolumn{2}{|c|}{ Policy Alternatives } \\
\hline & & & PA-1 & PA-2 \\
\hline \multirow[t]{2}{*}{$\begin{array}{l}\text { Strengthen health } \\
\text { care (Equity) }\end{array}$} & $\begin{array}{l}\text { 1. The main objective } \\
\text { of the policy } \\
\text { intervention is to } \\
\text { increase public health } \\
\text { coverage by reducing } \\
\text { out of pocket } \\
\text { expenditure from the } \\
\text { current } 64 \% \text { to } 32 \% \\
\text { by } 2032 \text { with public } \\
\text { fund primarily to } \\
\text { cover the premium of } \\
\text { people living under } \\
\text { below poverty line. }\end{array}$ & $\begin{array}{l}\text { Minimizing Out } \\
\text { of Pocket (OOP) } \\
\text { Expenditure } \\
\text { from } 64 \% \text { to at } \\
\text { least } 32 \% \text {. }\end{array}$ & 1 & 2 \\
\hline & $\begin{array}{l}\text { 2. The objective of } \\
\text { the policy is to } \\
\text { increase government } \\
\text { total health } \\
\text { expenditure as a } \\
\text { percentage of total } \\
\text { heath expenditure } \\
\text { from } 26 \% \text { to at least } \\
30 \% \text { by } 2032\end{array}$ & $\begin{array}{l}\text { Increase } \\
\text { government } \\
\text { health } \\
\text { expenditure from } \\
26 \% \text { to } 30 \%\end{array}$ & 1 & 2 \\
\hline
\end{tabular}




\begin{tabular}{|c|c|c|c|c|}
\hline \multirow[b]{2}{*}{ Goal } & \multirow[b]{2}{*}{ Objectives } & \multirow{2}{*}{$\begin{array}{c}\text { Criteria for } \\
\text { measurement }\end{array}$} & \multicolumn{2}{|c|}{ Policy Alternatives } \\
\hline & & & PA-1 & PA-2 \\
\hline $\begin{array}{l}\text { Make affordable } \\
\text { health protection } \\
\text { scheme to cover all } \\
\text { the people of } \\
\text { Bangladesh. } \\
\text { (Efficiency) }\end{array}$ & $\begin{array}{l}\text { 1.To provide free, } \\
\text { compulsory } \\
\text { contributory and } \\
\text { voluntary } \\
\text { participation health } \\
\text { care protection for } \\
\text { the people living } \\
\text { below poverty line of } \\
31.5 \% \text {, formal sector } \\
\text { of } 12.3 \% \text { and the } \\
\text { informal sector of } \\
56.2 \% \text { people } \\
\text { respectively from less } \\
\text { than } 1 \% \text { to at least } \\
32 \% \text { by } 2032 \text {. }\end{array}$ & $\begin{array}{l}\text { Increase the } \\
\text { number of } \\
\text { coverages from } \\
\text { less than } 1 \% \text { to at } \\
\text { least } 32 \% \text { by } \\
2032 \text { through } \\
\text { multiple health } \\
\text { protection } \\
\text { scheme }\end{array}$ & 0 & 2 \\
\hline \multirow[t]{2}{*}{$\begin{array}{l}\text { Ensure standard level } \\
\text { of health expenditure } \\
\text { (Fiscal } \\
\text { Sustainability/Budget } \\
\text { Availability) }\end{array}$} & $\begin{array}{l}\text { 1. The underlying } \\
\text { objective of the policy } \\
\text { is to increase total } \\
\text { public expenditure on } \\
\text { health per head US\$ } \\
8.32 \text { to at least US \$ } \\
34 \text { by the year } 2032 \text {. }\end{array}$ & $\begin{array}{l}\text { Increase per } \\
\text { capita health } \\
\text { expenditure }\end{array}$ & 0 & 2 \\
\hline & $\begin{array}{l}\text { 2. To increase total } \\
\text { public expenditure at } \\
\text { least } 15 \% \text { as a } \% \text { of } \\
\text { total public } \\
\text { expenditure from the } \\
\text { current } 4.3 \% \text { for } \\
\text { achieving the } \\
\text { universal health } \\
\text { coverage by } 2032 .\end{array}$ & $\begin{array}{l}\text { Increase and } \\
\text { maintain the } \\
\text { progressive } \\
\text { trends of } \\
\text { expenditure }\end{array}$ & 1 & 2 \\
\hline \multicolumn{3}{|c|}{ Total } & 3 & 10 \\
\hline
\end{tabular}

\section{Findings}

In the data analysis six criteria were used in order to assess and analyze the performance of alternative policies in regard to attaining three set-goals (Equity, efficiency, and fiscal sustainability). Two criteria of measurement for equity, one criterion for efficiency and two criteria for fiscal sustainability goals were used to measure the performance of the alternative policies. From analysis of secondary data, document research and my own ideas about the situation of Bangladesh and prediction of valuating impacts the policy alternative (PA-2) is the best. If government introduce multiple health protection schemes and create health protection fund especially for the people living below poverty line the household out of pocket expenditure will decrease from $64.0 \%$ to $32 \%$ by the year 2032. It can cover other segments of population through contributory compulsory health protection schemes for those working in the formal sector and 
64 An analysis of alternative policy for health care spending in Bangladesh

voluntary health protection schemes for those are in the informal sector the middleand upper-class people and it is approximately $32 \%$ (the three segments) and the pure government expenditure can cover $30 \%$ as a percentage of total health expenditure. It was also found and suggested that government should increase per capita health expenditure at least US\$ 34from current US\$ 8.32and increase the percentage share of health budget at least $15 \%$ of total expenditure by 2032 in order to attain the goal of universal health coverage.

\subsection{Recommendations and policy implications}

Depending and considering on the preceding data, facts and figures, analyses, projected outcomes and impacts, It will be recommended to the Ministry of Health and Family Welfare, Government of Bangladesh responsible for formulating health and family welfare related policies to adopt the proposed Policy Alternative 2 (current national health policy plus introduction of multiple health insurance schemes as alternative sources of health care financing) in order to ensure universal health coverage and accessibility of quality health services for the people of Bangladesh by 2032. In addition, it can be given to the directorate of the health services and the directorate of family planning the implementing agencies. The overall policy recommendations are as follows:

- Recommending the policy problem and analysis as the incremental model of policy making process and government can implement as pilot project in a district. If the pilot project is successful then it can be implemented in the whole country.

- Bangladesh should formulate a law of health protection covering different segment of people.

- Create Health protection fund especially for the people living with below poverty line to reduce the out of pocket (OOP) expenditure.

- Introduce health insurance as alternative sources of health care spending in Bangladesh both government and private sectors.

- Create and facilitate health insurance market place with similar facilities of each insurance company.

- Create compulsory health insurance provision in the existing life insurance companies and set a target of covering yearly basis.

- Increase and expand health care spending at least $15 \%$ of total government expenditure for ensuring universal health coverage by the year 2032

- Increase per capita government health expenditure as per World Health Organization standards.

- Reduce out of pocket expenditure (OOP) from $64 \%$ to $32 \%$. Because of out of pocket expenditure and other public services expenditure $15 \%$ poor people are facing catastrophic expenditure that leads to push them into poverty. The high 
OOP mean that people do not want to seek health care when they need it. If we see the United States the OOP is only around $16 \%$.

- Invest more on producing Human Resources for Health (HRH) and requisite infrastructure for generation of human resources specially doctors and trained nurses.

- Ensure efficient use of existing resources and make sure maximum utilization of annual allocation of government health budgets.

- Mobilize more resources for effective and quality health services for all.

- Innovation is indispensable for effective health care delivery system using ICT, research and development and modern technology.

- Need to strengthen institutional capacity building of all primary, secondary and tertiary levels of government and private hospitals before launching health insurance.

- Need to establish National health security office under the ministry of health and family welfare.

- Bangladesh need to increase per capita income at least US\$ 6500 to reach the goal of universal health coverage as we have seen the countries that already experienced universal health coverage. For example, Japan was set their goals of universal health coverage in 1922 and achieved the target in 1961 at that time its per capita income was US\$4291.

- Prioritizing health as one of the most important sectors it should reflect in the national budget as we have seen that the share of budget for health ministry is decreasing over the period.

\subsection{Probable Advantage}

The underlying advantage of the proposed policy is that it can mobilize internal resources through introduction of multiple health insurance schemes (contribution, taxes, government expenditure, copayments - with ceiling and exemption for the low income or people living with below poverty line). In this way Bangladesh can mobilize internal resources that can be invested in other productive sector that leads to increase total GDP, employment generation and per capita income of the country. Ultimately Bangladesh will become a healthy nation both economically and physically and can achieve and ensure the universal health coverage.

\subsection{Disadvantage}

At the outset of the implementation of the policy might not be deemed trouble-free as it comes with an additional component, i.e. multiple health insurance schemes and it needs related laws for health protection schemes and increasing public investment in health sectors. In this regard, the policy implementers must develop a comprehensive 
strategy for health care spending including the health protection schemes and fixing the target of achieving universal health coverage by 2032. The other challenges of universal health coverage are to develop institutional capacities and facilities to produce adequate Human Resources for Health (HRH) especially the trained nurses as there is massive gap of supply and demand of health providers. The other careful attention of the policy implementation is to create a proper monitoring authority for the health insurance providers and as Bangladesh is lacking experienced and knowledgeable government officers in this sector.

\section{Concluding Remarks}

Health care is indispensable for increasing the productivity of human beings. Almost every state in the world gives priority of government spending on health sectors for human development and economic growth from the increasing and reasonable demand of the citizens as constitutional rights. Bangladesh has experienced remarkable success in health indicators for achieving health related goals of MDGs and the current SDGs. But there is long way to go for ensuring universal health coverage as declared that has not taken proper steps to start the journey. Bangladesh is facing insufficiency of health care financing and is far behind the projected fund that is needed for covering universal health coverage.

There are alternative sources of health care financing by introducing multiple health insurance schemes. Some countries in Asia that have experienced universal health coverage like Japan and Thailand. Japan has experienced the universal health coverage in 1961 and declared the goal in 1922 by introducing various types of health protection schemes and huge public investment in health sectors. Thailand is also a very successful country for universal health coverage through huge government spending and alternative sources of health care financing like multiple health insurance schemes. Bangladesh needs lot of preparation for universal health coverage as there is shortage of Human Resources for Health $(\mathrm{HRH})$ specially the doctor, trained nurses and midwives. It also needs the capacity building of health institutions especially the government hospitals before launching the multiple health insurance schemes. Bangladesh should immediately introduce the health protection schemes at least for the people living below poverty line and formal sector otherwise it may raise the catastrophic poverty of health expenditure as the household out of pocket expenditure increases.

\section{Authorship}

Dr. Md. Mohoshin Ali and Dr. Shamim Akter parallelly contributed to the current study report. Both the author conceptualized and designed the study and collected data and analyzed. While Dr. Md. Mohoshin Ali drafted the manuscript for publication.

\section{Acknowledgements}

This study was made possible through the encouragement of Dr. Mohammad Mizanur Rahman, former Director of BPATC. 


\section{Funding}

The authors did not receive any financial support from any organization for research and publication.

\section{Declaration of conflicting interests}

The authors of the research declare no conflicting interests/issues among them.

\section{References}

Bardach, E. (2000). A Practical Guide for Policy Analysis: The Eightfold Path to More Effective Problem Solving. Chatham House: New York.

NIPORT, Dhaka, Bangladesh. (2011). Bangladesh Demographic and Health Survey

Bhuiya A. (2015). Universal health coverage. Bangladesh perspective, The Daily Star, $8^{\text {th }}$ March 2015. Available at www.thedailystar.net/universal-health-coveragebangladesh-perspective-64453.

Buracon, P (2011) The determinants and distributional effects of public education, health, and welfare spending in Thailand. Asian Affairs, An American Review, 38(3):3-38

Champook, P et al. (2009) Thailand, health system and pandemic preparedness, Rapid situational analysis report. Available at http://s3.amazonaws.com/zanran_storage/ www.cdprg.org/ContentPages/2475491875.pdf

Ministry of Health and Family Welfare. Directorate General of Health Services (2014). Health Bulletin

Health Population Nutrition Sector Development Programme (2011-2016). Reports

Health Watch. (2011) Bangladesh Health Watch Report

Hui K (2015). Universal health coverage. Bangladesh perspective, The Daily Star, available at www.thedailystar.net/universal-health-coverage-bangladesh-perspective-64453.

Hussain Z (2015) Universal health coverage. Bangladesh perspective, The Daily Star, $8^{\text {th }}$ March 2015, available at www.thedailystar.net/universal-health-coveragebangladesh-perspective-64453.

ILO (2008) Thailand universal health care coverage through pluralistic approach. Available at https://www.ilo.org/wcmsp5/groups/public/---ed_protect/--soc_sec/documents/publication/wcms_secsoc_6612.pdf 
Islam MT (2015). Universal health coverage. Bangladesh perspective, The Daily Star, available at www.thedailystar.net/universal-health-coverage-bangladeshperspective-64453.

Maruf. H (2013). GO-NGO Collaboration in Health Sector Management of Bangladesh: An Evaluation of BRAC's Health Programme

Ministry of Finance Bangladesh. (2015). Bangladesh Economic Review

Ministry of Finance Bangladesh (2015-2016). National Budget data

NaRanong, V., NaRanong, A. (2006). Universal Health Care Coverage: Impacts of the 30-Baht Health-Care Scheme on the Poor in Thailand. TDRI Quarterly Review, 21(3), 3-10.

Penkarn K (2005). Impact of the 30-Baht health insurance policy on hospital drug utilization in Thailand.

Rahman Re (2007). (2007) The State, the Private Health Care Sector and Regulation in Bangladesh. The Asia Pacific Journal of Public Administration, vol.29, no.2 (December 2007):191-206

Soetersand R., Griffiths F. (2003), Improving government health services through contract management: a case from Cambodia. Health policy and planning, Oxford University Press

Sameh El-Saharty et al. (2015), The Path to Universal Health Coverage in Bangladesh, Bridging the Gap of Human Resources for Health, World Bank Study Report

Sajani, TT et al. (2014). Public private partnership in health sector of Bangladesh.

United States Department of Health and Human Services. (2020-2021) Reports. Available at https://www.hhs.gov/

Weimer D L, Vining, A R. (2011). Policy Analysis: Concepts and Practice. Prentice Hill: New Jersey.

WHO (2011) National Bangladesh Health Policy. Available at https://www.who.int/ workforcealliance/countries/bgd/en

World Bank data. Available at https://www.worldbank.org/en/country/bangladesh

World Health Organization data. Available at https://www.who.int/bangladesh 